Please note: This is the final revision draft of this paper. The published final version is available as follows:

Randolph, G.M. 2010. Measuring the Indirect Effect: Voter Initiatives and Legislative Production in the American States. Public Finance Review 38 (6): 762 - 786.

\title{
Measuring the Indirect Effect: Voter Initiatives and Legislative Production in the American States
}

\author{
Gregory M. Randolph* \\ Department of Finance \& Economics \\ Southern New Hampshire University \\ 2500 North River Road \\ Manchester, NH 03101 \\ g.randolph@snhu.edu \\ (603) 668-2233 x.3315
}

\begin{abstract}
Recent research has identified important policy differences between voter initiative states and pure representative states despite a lack of enough observable voter initiative campaigns to explain the policy differences. This paper investigates the indirect effects of the voter initiative process on legislative production by estimating the number of bills enacted in the American states. The results indicate that legislators in voter initiative states enact more legislation as the difficulty in qualifying a voter initiative for the ballot decreases, as the legislature is less able to alter the effects of successful voter initiatives, and as the average number of voter initiatives that appear on the ballot increases. These results provide some statistical evidence of the indirect effect of the voter initiative and are consistent with the theory that policy differences in voter initiative states are the result of the indirect effect of the voter initiative process.
\end{abstract}

Keywords: Direct Democracy, Fiscal Policy

JEL Codes: H11, H30, H71 
-2 - 


\section{Introduction}

A number of recent studies indicate that the voter initiative process has a significant impact on policy outcomes (Matsusaka 1995, forthcoming; Gerber 1999). The impact of the voter initiative process on state fiscal policy is one of the most intriguing findings of the literature. Matsusaka $(1995,2004)$ finds that voter initiative states have a lower level of state spending, rely less on taxes and more on user fees, and employ a greater degree of local government spending relative to states in which the voter initiative process is unavailable from 1960 - 1990. Additionally, Matsusaka (2000) shows that voter initiative states in the first half of the century relied more on local expenditures than state level expenditures than pure representative states. However, it is interesting to note that these important fiscal policy differences between voter initiative and non-initiative states persist despite the lack of enough observable ballot measures to drive the observed policies.

The absence of observable successful ballot measures that directly impact state policy suggests the presence of an indirect effect of the voter initiative process. Gerber (1998) notes that interest groups may be able to influence policy outcomes at a lower cost by pressuring the legislature to enact policy changes with the threat of a voter initiative. Additionally, interest groups that lack the resources to succeed with a voter initiative campaign may be able to signal their preferences to the legislature through the voter initiative process. The threat of a voter initiative can influence the state legislature to enact legislation in order to avoid the passage of a voter initiative. Additionally, a potential voter initiative issue may persuade legislators to enact legislation when they perceive that the issue is supported by their constituents. The indirect effects of the voter initiative process are examined in greater detail in Gerber $(1996,1998)$, Matsusaka and McCarty (2001), Boehmke (2005), and Matsusaka (2007). 
However, there are other possible indirect effects of the voter initiative process as well. Matsusaka and McCarthy (2001) note that the voter initiative process may allow the legislature to leave some issues to the voters to decide directly when enough uncertainty regarding voter preferences is present. Furthermore, the voter initiative process may allow legislators to avoid taking decisive action on controversial decisions (Magleby 1984; Cronin 1989). In these cases, the passage of a voter initiative could act as a substitute for activity in the state legislature. Recently, controversial issues such as same-sex marriage and eminent domain have appeared frequently on ballots as voter initiatives.

While previous research has examined fiscal policy outcomes in voter initiative states relative to pure representative democracy states and provided a theory by which the indirect effect of the voter initiative process can influence policy outcomes, the literature has yet to provide statistical evidence regarding the influence of the voter initiative process on legislative behavior. In theory, the availability of the voter initiative process can result in an increased level of activity on the part of the state legislature. The legislature may enact legislation in order to avoid a potentially unfavorable voter initiative outcome or simply to please their constituents. It is expected that legislators in voter initiative states produce more legislation in order to deal with the additional pressures of the voter initiative process. Alternatively, the availability of the voter initiative process also allows the state legislature to defer to the voters when voter preferences are sufficiently uncertain or issues are extremely controversial.

This paper examines the number of bills enacted in the American states in order to examine the overall effect of the voter initiative process on the production of legislation by the state legislature. The results suggest that state legislatures in voter initiative states enact more legislation as the difficulty to qualify a voter initiative for the ballot decreases and as the 
insulation to the legislature from the passage of a voter initiative decreases. Additionally, legislatures appear to enact more legislation in states where voter initiatives are more likely to appear on the ballot. These findings provide some statistical evidence of the presence of the indirect effect of the voter initiative process as legislators in voter initiative states are more active than their counterparts. Additionally, the results are consistent with the scenario in which the observed policy differences between voter initiative states and non-initiative states are the result of legislation enacted due to the threat or signal of the voter initiative process.

\section{The Indirect Effect of the Voter Initiative}

The voter initiative is a ballot measure that may be used to enact a new law or constitutional amendment. A voter initiative can qualify for the ballot when a specified number of signatures are collected to show support for a policy change. Signature requirements vary by state and generally refer to a percentage of the number of votes cast in the previous state gubernatorial election. The voter initiative process is available in twenty four states, which are listed along with the corresponding signature requirements in Table 1 (Initiative and Referendum Institute 2009).

Gerber (1998), Gerber and Hug (2001) and Matsusaka (2007) provide thorough discussions of both the direct and indirect effects of the voter initiative process. The direct effects of the voter initiative occur when the voters approve of a voter initiative that has been placed on the ballot. When this is the case, voters are able to immediately and directly affect policy outcomes. Although the direct effects of the voter initiative seem relatively easy to observe, some policies enacted through successful voter initiative campaigns may have been enacted by the state legislature in the absence of the voter initiative process. Additionally, the 
state legislature may be able to diminish the impact of a successful voter initiative campaign. However, the indirect effects of the availability of the voter initiative process are less straightforward and require some additional discussion in order to identify how they may affect policy outcomes.

Gerber (1998) and Boehmke (2005) discuss the behavior of interest groups in voter initiative states and how these behaviors can indirectly lead to policy changes. Gerber (1998) notes that interest groups may use the voter initiative process as a means to threaten the state legislature into making a policy change. An interest group may be able to obtain a policy change at a lower cost if they are able to influence the legislature to alter a policy relative to the expenses involved in a successful ballot measure. Additionally, interest groups may use the voter initiative process to signal the preferences of the group. State legislatures may disagree with the policy preferences or be unaware of the preferences of constituents. However, if the interest group can signal significant support, the legislature may find it in their interest to enact a policy that is supported by constituents. Due to the availability of the voter initiative process as a means to pursue policy goals, Boehmke (2005) finds that voter initiative states have significantly more interest groups than non-initiative states. Additionally, he shows that the interest groups in voter initiative states tend to be less wealthy groups with larger membership than interest groups in non-initiative states. Rather than using traditional lobbying approaches, these broad based groups in voter initiative states tend to employ strategies that involve their large membership in order to influence the legislature.

Gerber (1996) and Matsusaka and McCarthy (2001) discuss the details of the decision making process of the legislature when faced with the possibility of a voter initiative. Legislatures in states in which the voter initiative process is available must consider potential 
voter initiative campaigns that interest groups may use in an attempt to achieve their policy goals. Additionally, any legislation that is enacted by the legislature could be challenged with a voter initiative. If these voter initiatives are successful, they could lead to the adoption of policies that contrast with the preferences of the legislature. Additionally, the legislature may simply become aware of the preferences of their constituents through the voter initiative process. Therefore, legislators may preemptively enact legislation due to the threat or signal of a potential voter initiative campaign.

Gerber (1996) models the behavior of the legislature in a sequential game in which there are three players: the legislature, an interest group that proposes a voter initiative, and the voter. The objective of each of the players is to select the policy that results in the highest utility level. The model provides the framework in which the legislature makes decisions when the voter initiative is available. In the end, the legislature will enact legislation if it provides a greater benefit (or less of a loss in utility) than the possible voter initiative. In order for the legislature to react to a potential voter initiative, an interest group must convince the legislature that a voter initiative campaign is a credible threat by displaying a certain level of support for a proposal.

When information is complete, the legislature will only enact policies that benefit the median voter due to the threat of a voter initiative campaign (Matsusaka and McCarthy 2001). Voter initiatives never reach the ballot in these situations as the legislature will always preemptively enact a policy once an interest group provides a credible threat. However, policies that harm the median voter can be enacted when information is not complete as fringe interest groups may be able to influence the legislature.

While the indirect effect of the voter initiative process as discussed above seems to lead to an increase in the level of legislative activity, successful voter initiative campaigns may 
replace legislation in some cases. When the state legislature is uncertain regarding voter preferences on a particular issue, the legislature may choose to allow voters to decide a policy outcome through the voter initiative process (Matsusaka and McCarthy 2001). Furthermore, Magleby (1984) and Cronin (1989) note that the voter initiative may allow the legislature to avoid making difficult decisions. The legislature may choose inaction as opposed to making an unpopular decision that could hamper their reelection chances. While legislators in pure representative states must enact legislation for all policy changes, legislators in voter initiative states may allow the voters to decide the outcome of these decisions through a voter initiative. This type of legislative inaction could lead to a reduction in the number of policy decisions made by the legislature in voter initiative states.

While a number of recent empirical investigations have indicated that the presence of the voter initiative has significant policy effects, there is little evidence that specifically attributes these effects to the indirect effect of the voter initiative process. Matsusaka $(1995,2004)$ finds that states in which the voter initiative process is available have lower levels of spending and taxes, more user fees, and more local spending in comparison to states that lack the voter initiative process. Many of these policy effects occurred without the direct proposal of a voter initiative. Gerber (1998) provides some anecdotal evidence of the indirect effect of the voter initiative process by examining some specific examples in which interest groups appeared to influence the policy decisions of state legislatures through the threat of a voter initiative campaign. Additionally, Matsusaka (2007) evaluates the direct and indirect effects of the voter initiative process on several specific outcomes by employing dummy variables for the availability of the voter initiative process, whether a voter initiative appeared on the ballot, and whether a voter initiative that appeared on the ballot was adopted. While the previous research 
has chronicled differences in policy outcomes and examined some specific policy cases between voter initiative and non-initiative states, the indirect effect of the voter initiative process on the behavior of the legislature has yet to be statistically evaluated.

This study contributes to the literature by examining the indirect impact of the voter initiative process on legislative production in the American states. In theory, the availability of the voter initiative process causes the legislature to produce more legislation in order to avoid unfavorable voter initiatives and to satisfy constituents when a potential voter initiative signals support for an issue to the legislature. A difference in legislation between voter initiative and non-initiative states would provide some statistical evidence of the indirect effect of the voter initiative process. However, the availability of the voter initiative process may decrease legislation if the legislature is unaware of constituent preferences or defers difficult decisions to the voter initiative process. This paper statistically examines the indirect effect of the voter initiative process by estimating the impact of the voter initiative process on the number of bills enacted by state legislatures.

\section{Measuring Legislative Production}

In order to assess the impact of the voter initiative on the production of legislation in the American states, this section of the paper specifies an empirical estimation of the number of bills enacted by state legislatures. Numerous studies have examined the production of legislation, although the vast majority of the research in the area focuses on the federal government. Crain (1979) and Tollison (1988) investigate the primary determinants of legislative productivity. Mayhew (1991), Kelly (1993), Brady and Volden (1998), Krehbiel (1998), and Howell, et al. (2000) examine the impact of divided government on the production of legislation at the national 
level. The studies examine legislation of different levels of significance in an attempt to include only important legislation. Rogers (2005) estimates legislative production in the American states in order to examine the issue of divided government.

This study examines the number of bills enacted at the state level. Following Rogers (2005), this analysis includes all bills passed rather than using some measure of significant legislation. Given the vast number of bills enacted in states each year, it is extremely difficult and subjective to identify significant state level legislation. Additionally, it is plausible that a number of small bills can combine to have significant effects. Rogers (2005) uses the number of bills enacted in state legislatures by chamber of origin to assess the difference between divided branch government and divided party government. This study uses the number of bills enacted at the state level in order to evaluate the impact of the voter initiative process because data on the chamber of origin is unavailable for many states.

Following previous theoretical and empirical theory, a number of important variables are included to account for differences between states and state legislative processes. The log of population is included as a proxy for the demand of legislation (Rogers 2005) and because the per capita costs of laws are lower with a greater population (Tollison 1988). These concepts suggest that states with higher populations will enact more legislation. The length of the legislative session varies across states and tends to impact the number of bills that are enacted in the session. A variable that measures the actual number of legislative business days in a session is included. Longer legislative sessions may lead to an increase in the production of legislation as legislators have more time to enact legislation once the start up costs of convening a session are overcome (Crain 1979), although a large majority may achieve high rates of output in a short 
session (Crain 1979; Crain, Shugart, \& Tollison 1988). Rogers (2005) finds evidence that longer legislative sessions lead to the production of more legislation.

There are two clauses that some states employ in an attempt to regulate legislation. Forty-one states have a constitutional provision requiring a single subject clause that limits each bill to one particular topic. Additionally, eighteen states have a constitutional provision for an origination clause that requires all revenue bills to originate in the house chamber of the state legislature. While many previous legislative productivity studies at the national level did not have to consider these issues, two dummy variables are used to control for these clauses at the state level following Rogers (2005). States in which the clauses do not exist are the excluded group. In theory, the revenue bill of origination clause is expected to decrease legislative production as the state senate is unable to initiate revenue bills. However, the effect of the single subject clause is somewhat ambiguous. While it may increase the number of bills enacted as larger bills must be separated into individual bills, the clause may decrease the number of bills enacted as logrolling opportunities among legislators are reduced (Rogers 2002).

A dummy variable is included to account for sessions in which the state legislature was divided by party affiliation. This occurs when the house and senate of a state legislature consist of a majority of opposite political parties. Divided branch government is also included by incorporating a dummy variable that takes the value of one if the governor is the opposite political party of a unified legislature. While the theoretical expectation is that divided government would decrease the production of legislation, numerous studies at the national level failed to identify any impact of divided government on the production of legislation (Mayhew 1991; Kelly 1993; Krehbiel 1998). However, Rogers (2005) finds that divided legislative government significantly reduces legislative production while divided branch government does 
not have a significant effect at the state level. Additionally, Alm and Evers (1991) find that the item veto for state governors slightly reduces and alters the composition of state government spending when the parties of the governor and the legislature differ.

A larger majority should lead to an increase in the production of legislation as the majority is better able to meet the required number of votes to enact a bill. However, diminishing returns are expected as the majority grows because it becomes more difficult to monitor majority members and assign members to their most valued use (Crain 1979; Tollison 1988). The logged percentage of Republican legislators in both the state house and senate are included to examine the impact of a larger majority on legislative production. It is also expected that legislative influence increases with seniority (Tollison 1988). Legislators may gain information, skills, and relationships though their experiences in the legislature (Rogers 2005). The percentage of new legislators that join both the house and the senate from the previous year's election are included in order to assess the impact of legislative turnover on legislative production. It is expected that a higher percentage of new legislators will lead to less legislative production. Another dummy variable accounts for the party of the governor in the state. Rogers (2005) includes a Republican governor variable in order to test if Democratic governors tend to enact more legislation. Besley and Case (1995) and Leigh (2008) find that there are some differences in specific policies between Republican and Democratic governors. The dummy variable takes a value of one if the state governor is a Republican.

A larger number of legislators increase the cost of reaching a legislative decision, but larger legislatures may be able to specialize and interest groups may be able to acquire more votes for a specific level of expenditure with more legislators (Crain 1979; Tollison 1988). The numbers of state house and senate legislators are included to account for these possible effects. 
Rogers $(2002,2005)$ finds that greater numbers of legislators lead to the production of more legislation in both the state house and senate. Legislative committees are expected to increase the production of legislation as committees are thought to decrease the incentives to free ride (Crain and Tollison 1982; Rogers 2002), help legislators to gain specialized knowledge (Gilligan and Krehbiel 1987; Krehbiel 1998), and assist legislators in achieving personal goals (Mayhew 1974). Variables are included to account for the number of house standing committees, senate standing committees, and joint standing committees. Similarly, legislative staff may help to facilitate the production of legislation through increased specialization (Tollison 1998; Rogers 2005). The average number of staff members available to house and senate legislators is included in the analysis.

Additionally, state government ideology varies widely across states. Nelson and Silberberg (1987) and Tollison (1988) note that legislators respond rationally to constituent ideology and ideology plays an important role in the outcome of legislation. A measure developed by Berry, et al. (1998) is used to examine the role of ideology in the production of legislation. $^{2}$ Tollison (1988) observes that there are a number of economic incentives that influence the composition and behavior of legislatures. An index developed by Squire (1992) and expanded by King (2000) that measures legislative professionalism is used to assess the impact of different types of individuals in the state legislature. ${ }^{3}$

While state fixed effects cannot be employed as their inclusion would result in perfect collinearity with the voter initiative variables, regional dummy variables are included to account for any differences across regions in the U.S. While there are states in each region of the U.S. that have access to the voter initiative process, the majority of the voter initiative states are in the West. Additionally, there may be other differences in legislative behavior between regions in the 
U.S. Variables for the North, South, and West are included while the Midwest is the excluded region. $^{4}$ Additionally, year dummy variables are included to account for time fixed effects.

Several methods are employed in order to examine the effect of the voter initiative on the number of bills enacted. The first specification includes a dummy variable to account for voter initiative states. States in which the voter initiative process is available receive a value of one while states that lack the voter initiative process are the excluded group. ${ }^{5}$ However, voter initiative states differ in the amount of signatures that are required in order to place a voter initiative on the ballot. The signature requirement generally refers to the percentage of the previous gubernatorial election votes that must be collected and varies from a low of three percent to a high of fifteen percent (Initiative and Referendum Institute 2009). The difference in the signature requirement results in substantial variation in the effects of the voter initiative process as it can be very difficult to collect the necessary signatures in high requirement states. The voter initiative states and the corresponding signature requirement are displayed in Table 1.

Additionally, states differ in other ways regarding the qualifications necessary to successfully place a voter initiative on the ballot and the extent to which the legislature can mitigate the impact of a successful voter initiative. In order to further evaluate the effects of the voter initiative process, several alternative measures of the voter initiative process are examined. Bowler and Donovan (2004) introduce two indices to account for differences in voter initiative methods between states. The qualification difficulty index measures the complexity of qualifying a voter initiative proposal for the ballot. The qualification difficulty index ranges from zero to six based on the necessary requirements to qualify a proposal for a ballot. It is substantially easier to place a proposal on the ballot in states with higher values. The legislative insulation index measures the extent to which the state legislature can mitigate the effects of a 
successful voter initiative. The legislative insulation index ranges from zero to nine. Legislatures in states with higher values have a lesser ability to block the effects of a successful voter initiative. ${ }^{6}$ States that lack the voter initiative process receive a value of zero in each index. Additionally, the average number of voter initiatives that appear on the ballot each two year election cycle from 1970 - 2002 is employed in order to roughly gauge the likelihood of a voter initiative appearing on the ballot. While it is impossible to accurately measure the threat of a voter initiative campaign due to unavailable data regarding potential voter initiative campaigns, the average number of voter initiatives provides a measure of the frequency of voter initiative use (Tolbert, Grummel, and Smith 2001; Bowler and Donovan 2004). Table 1 displays the values of each of the Bowler and Donovan (2004) variables and the average number of voter initiatives for voter initiative states.

The dependent variable is the number of bills enacted by the American states during the regular legislative session in odd years from 1981 - 1995, 1998, 2000, and 2001. While almost all states hold legislative sessions annually, the dependent variable and a number of the independent variables are reported biennially in The Book of the States (Rogers 2005). Data sources are listed in Table 2. Summary statistics are presented in Table 3.

\section{Regression Results and Discussion}

The results of the analysis with dummy variables for voter initiative states, the qualification difficulty index, the legislative insulation index, and the average number of voter initiatives are presented in Table 4. Due to the panel nature of the data, it is likely that interclass correlation may be an issue for legislative production observations within a state over time. When unaccounted for, this correlation can cause significance tests to be invalid as standard errors may 
be misestimated. In order to correct for this possible problem, clustered standard errors are employed in all estimates with the exception of column (a). Clustered standard errors were omitted in column (a) for comparison purposes.

Column (a) of Table 4 shows that states with the voter initiative enact more bills per year than states that lack the voter initiative process. Voter initiative states enact an average of approximately sixty-eight more bills per session than non-initiative states, significant at the ten percent level. However, the voter initiative dummy variable is not significant in column (b) in Table 4 when clustered standard errors are employed. While the coefficients in column (b) remain unchanged from column (a), standard errors are larger in the analysis with clustered standard errors. However, it is important to remember the differences between voter initiative states. Different signature requirements and other restrictions make the voter initiative process much more accessible and useful in some states than others. The dummy variable for voter initiative states does not account for these differences between states, combining states with strong and weak voter initiative processes together.

The specifications using the Bowler and Donovan (2004) variables accounting for differences between voter initiative processes, reported in columns (c) and (d) of Table 4, suggest that the voter initiative process leads to greater legislative productivity. Column (c) of Tables 4 shows that legislatures in voter initiative states where the qualifications for placing a proposal on the ballot are relatively simple create significantly more legislation than voter initiative states with restrictive qualifications. The coefficient for qualification difficulty is highly significant at the one percent level and indicates that legislation is increased by approximately forty bills as the index for the accessibility to the voter initiative process increases by one unit. Column (d) of Table 4 displays that state legislatures are more active in voter 
initiative states where the legislature is more restricted in their ability to mitigate the effects of the passage of a successful voter initiative. The coefficient for legislative insulation is highly significant at the one percent level and indicates that legislation is increased by thirty-two bills as the index for the insulation to the state legislature from the voter initiative process increases by one unit. These estimates suggest that states that have relatively easy access to the voter initiative process and policies that shield successful voter initiatives from the state legislature tend to have a greater level of legislative production relative to voter initiative states with weaker voter initiative processes.

Column (e) of Table 4 displays the regression results for the empirical specification including the voter initiative dummy, qualification difficulty index, and the legislative insulation index together. The voter initiative dummy variable is significant at the one percent level, the qualification difficulty index is significant at the ten percent level, and the legislative insulation index is insignificant in the analysis. The coefficient for the voter initiative dummy variable is approximately negative four hundred. As the qualification difficulty index increases by one unit, state legislatures produce approximately ninety-four more bills per session. Considering the qualification difficulty index as an interaction term with the voter initiative dummy variable, the qualification difficulty index must be five or greater in order for the availability of the voter initiative process to have a significant positive effect on the production of legislation. This provides further evidence that an accessible voter initiative process is necessary to generate greater legislation.

Finally, column (f) of Table 4 reports the coefficients for the empirical estimation including the average number of voter initiatives that appear on the ballot each two year election cycle from 1970 - 2002. As the average number of voter initiative measures on the ballot 
increases by one, approximately eighty-three additional bills are produced, significant at the one percent level. This provides some evidence that state legislatures are more active as the likelihood that a voter initiative will appear on the ballot increases. ${ }^{7}$

\subsection{Implications of the Voter Initiative Process}

These findings suggest that access to the voter initiative process and protection from the legislature for a successful voter initiative are important in shaping the behavior of the state legislature. The additional activity by the state legislature in voter initiative states provides some evidence of the indirect effect of the voter initiative process as legislators in voter initiative states enact more legislation than their non-initiative legislative counterparts. This finding is consistent with the theory that fiscal policy differences between voter initiative states and non-initiative states are the result of the indirect effect of the voter initiative process. The observed policy differences may be attributed to the additional legislation in voter initiative states.

Additionally, it appears that the mere existence of the voter initiative process may not be enough to influence legislator behavior. In order for the legislature to respond to the availability of the voter initiative process, the voter initiative process must be a serious threat. Legislatures in states with easier access to the voter initiative process and less legislative ability to block successful voter initiative campaigns appear more active. Furthermore, the results imply that the scenario in which legislation is reduced when the state legislature defers to the voter initiative process regarding uncertain or controversial issues are either insignificant or simply outweighed by the positive effects of the voter initiative process on state legislation. While we do not perceive any legislative reduction for these controversial issues, legislators may still defer to the voter initiative in a small number of cases, rendering them insignificant in this big picture study. 
Despite the significant findings in this study, it is important to consider some alternative interpretations of the results. It is extremely difficult to devise an empirical strategy that directly connects the threat of the voter initiative process with policy outcomes. We cannot completely dismiss the possibility of spurious correlation in which voter initiative states simply happen to enact more legislation than non-initiative states for unobserved reasons. Additionally, some recent research has asserted that the voter initiative process is endogenous to historical factors within states (Marschall and Ruhil 2005). However, Matsusaka (2005) provides evidence against the endogeneity issue, noting that the vast majority of voter initiative states gained access to the voter initiative process prior to 1915 (Matsusaka 1995).

It is also possible that the additional legislation that is observed in voter initiative states may occur due to other effects of the voter initiative process. While legislation may be a response to the threat of a voter initiative or a reaction to the realization of constituent preferences as considered previously, the additional legislation may also simply be the result of the state legislature enacting legislation due to successful voter initiative campaigns. Furthermore, the increased number of bills enacted may be the result of legislators' attempts to mitigate the effects of successful voter initiative campaigns. The positive and significant coefficient on the dependent variable for the average number of voter initiatives could be attributed to these possibilities. Despite the limitations of the study, the results offer the first empirical evaluation of the impact of the voter initiative process on legislative production and are consistent with the theory behind policy differences between voter initiative and noninitiative states.

\subsection{Other Variables of Interest}


Although the primary focus of the study involves the indirect effect of the voter initiative process, several other independent variables are of interest as well. The logged population coefficients indicate that approximately one additional bill is produced as the population increases by one percent, significant in the estimations at the five percent level. This follows the rationale that higher populations help to proxy the demand for legislation and the per capita costs of legislation are lower with greater population. The session length coefficient is positive and significant at the ten percent level in columns (b), (c), and (d) of Table 4, providing evidence that legislatures may enact more legislation when given more time to overcome the initial startup costs of the session. Additionally, this provides evidence against the theory that legislators achieve a higher output rate in a short time frame.

The large, negative coefficient on the dummy variable for a single subject clause for bills in columns (b) and (e) of Table 4 is significant at the ten percent level and suggests that single subject clauses may reduce legislative output. Additionally, the dummy variable for states that require revenue bills to originate in the state house is negative and significant at the ten percent level in column (d), providing some evidence that revenue bill clauses reduce legislation. The dummy variable for a republican governor is surprisingly significant at the five percent level in columns (b) and (d) and significant at the ten percent level in column (c), implying that republican governors may preside over more productive legislatures. However, the logged percentages of house and senate republicans are insignificant in all cases.

The state government ideology coefficient is significant at the ten percent level in columns (c) and (d), indicating that state legislatures may enact more legislation as their ideology score becomes more liberal. Finally, the regional variables indicate that states in the South and West appear to enact significantly more legislation than states in other regions. 
However, it is interesting to note that the variable for the West is insignificant when the average number of voter initiatives variable is included in column (f) of Table 4.

\section{Conclusion}

This paper examines the impact of the voter initiative process on legislative production in the American states. In theory, the threat of the voter initiative can cause the state legislature to preemptively enact legislation in order to avoid an unfavorable outcome from the passage of a voter initiative or simply to satisfy constituent interests when a potential voter initiative signals a high level of support for an issue (Gerber 1998; Gerber and Hug 2001; Matsusaka 2007). Additionally, the voter initiative process can theoretically lead to a reduction in legislation if the state legislature defers to the voter initiative process due to uncertainty or avoidance of controversial issues. The effects of the voter initiative process on legislation are particularly interesting given the differences in fiscal policies between voter initiative and non-initiative states (Matsusaka 1995, 2000, 2004).

The results in this paper suggest that the availability of the voter initiative causes state legislatures to be more active as citizens have easier access to the voter initiative process, state legislators are less able to block the impact of successful voter initiatives, and voter initiatives appear on the ballot more frequently. These findings provide some of the first statistical evidence of the indirect effects of the voter initiative process as voter initiative states appear to enact more legislation than their counterparts. The additional legislation is consistent with a scenario in which legislators in voter initiative states respond to the threat of the voter initiative process, resulting in the observed policy differences between voter initiative and non-initiative states. However, we cannot exclude the possibility that the additional legislation could be the 
result of state legislators enacting more legislation to deal with successful voter initiatives or unobserved reasons that the legislators in voter initiative states are more active.

These findings also provide some important implications for future research in the area. The degree to which the greater legislation found in voter initiative states helps align policy outcomes with voter preferences depends critically on the quality of information exchanged between agents in the voter initiative process. The additional legislation in voter initiative states may help align policy outcomes with voter preferences if information is complete, but may lead to policies further from the median voter's preferences with incomplete information. Additionally, the results in this study suggest that a more detailed analysis of the source and impact of the increased legislation in voter initiatives states could substantially increase our understanding of the indirect effects of the voter initiative process given the differences in policy outcomes between voter initiative and non-initiative states. 


\section{Notes}

* I am grateful to two anonymous referees, editor James Alm, and Russell S. Sobel for helpful comments and suggestions. I would also like to thank Angela K. Dills and participants at a session at the Southern Economic Association annual meetings.

${ }^{1}$ A voter referendum is a similar process that can be used to revoke a law or constitutional amendment that has been enacted by the state legislature. Additionally, state legislatures in all states can propose a policy through a legislative referendum (Initiative and Referendum Institute 2009). This analysis focuses on the voter initiative process as it is the tool that allows interest groups to propose new policies.

${ }^{2}$ Berry et al. (1998) construct an index of state government ideology by examining the division of the state legislature, the party of the governor, the outcomes of congressional elections, roll call for the state congress, and other assumptions about state politicians. This analysis uses the revised 1960-2006 government ideology series. It is available through the web site listed in the references. The index ranges from $0-100$, with higher scores indicating a more liberal government.

${ }^{3}$ Squire (1992) constructs a state index of legislative professionalism based on the length of the legislative session, the salary of legislators, and the staff size. King (2000) updates the index to account for other legislative expenditures.

${ }^{4}$ Regional variables are constructed as follows: North (CT, MA, ME, NH, NJ, NY, PA, RI, VT), South (AL, AR, DE, FL, GA, KY, LA, MD, MS, NC, OK, SC, TN, TX, VA, WV), Midwest (IA, ID, IL, IN, KS, MI, MN, MO, ND, NE, OH, SD, WI), and West (AK, AZ, CA, CO, HI, MT, NM, NV, OR, UT, WA, WY).

${ }^{5}$ Wyoming is not included as a voter initiative state because it has an extremely high signature requirement at fifteen percent. Illinois is not included as a voter initiative state because it is the only state in which a proposal can only be used to alter the organization of the state legislature. This follows the logic of Matsusaka (2004). The inclusion of Wyoming and Illinois does not significantly alter the results.

${ }^{6}$ Bowler and Donovan (2004) use the number of formal provisions required to place a voter initiative on the ballot in order to develop the qualification difficulty index. The number of provisions that restrict the ability of the legislature to alter the effects of a successful voter initiative are used to develop the legislative insulation index. Their indices have been reversed in this paper in order to simplify the interpretation of the indices. Bowler and Donovan (2004) find that reversing the indices do not alter the results. States that lack the voter initiative process receive a value of zero.

${ }^{7}$ Several additional empirical examinations were analyzed in order to verify the robustness of the results, although the results are excluded due to space limitations. These examinations include employing the log of the number of bills enacted as the dependent variable, investigating the number of bills enacted by decade, and performing an analysis consisting solely of the voter initiative states. The primary finding that greater access to the voter initiative process and greater insulation from the legislature for successful voter initiative campaigns tend to result in higher levels of legislative production is robust to the aforementioned changes. The robustness checks are available from the author upon request. 


\section{References}

Alm, James and Mark Evers. 1991. The Item Veto and State Government Expenditures. Public Choice 68: 1 - 15.

Berry, William D., Evan J. Ringquist, Richard C. Fording, and Russell L. Hanson. 1998. Measuring Citizen and Government Ideology in the American States, 1960 - 93. American Journal of Political Science 42 (1): 327 - 48.

Berry, William D., Evan J. Ringquist, Richard C. Fording, and Russell L. Hanson. State Citizen and Government Ideology [Online], (cited June 1, 2007). Available from: $<$ http://www.uky.edu/ rford/Home files/page0005.htm $>$.

Besley, Timothy and Anne Case. 1995. Does Electoral Accountability Affect Electoral Policy Choices? Evidence from Gubernatorial Term Limits. Quarterly Journal of Economics 110 (1995): 769 - 98.

Boehmke, Frederick J. 2005. The Indirect Effect of Direct Legislation: How Institutions Shape Interest Group Systems. Columbus: The Ohio State University Press.

The Book of the States. 1980 - 2003. Volumes 23 - 35. Lexington: The Council of State Governments.

Bowler, Shaun and Todd Donovan. 1998. Demanding Choices: Opinion and Voting in Direct Democracy. Ann Arbor: University of Michigan Press.

Bowler, Shaun and Todd Donovan. 2004. Measuring the Effect of Direct Democracy on State Policy: Not All Initiatives are Created Equal. State Politics and Policy Quarterly 4 (3): $345-63$.

Brady, David W. and Craig Volden. 1998. Revolving Gridlock: Politics and Policy from Carter to Clinton. Boulder: Westview Press.

Crain, W. Mark. 1979. Cost and Output in the Legislative Firm. Journal of Legal Studies 8 (2): $607-21$.

Crain, W. Mark. and Tollison, Robert D. 1982. Team Production in Political Majorities. Micropolitics 2 (1): $111-21$.

Crain, W. Mark, William F. Shugart, II, and Robert D. Tollison. 1988. Legislative Majorities as Nonsalvageable Assets. Southern Economic Review 55 (4): 303 - 14.

Cronin, Thomas. 1989. Direct Democracy: The Politics of Initiative, Referendum, and Recall. Cambridge: Harvard University Press. 
Gerber, Elisabeth R. 1996. Legislative Response to the Threat of Popular Initiatives. American Journal of Political Science 40 (1): 99 - 128.

Gerber, Elisabeth R. 1998. Pressuring Legislatures Through the Use of Initiatives. In Citizens as Legislators: Direct Democracy in the United States, Shaun Bowler, Todd Donovan, and Caroline Tolbert, eds., 191 - 208. Columbus: Ohio State University Press.

Gerber, Elisabeth R. 1999. The Populist Paradox: Interest Group Influence and the Promise of Direct Legislation. Princeton: Princeton Press.

Gerber, Elisabeth R. and Simon Hug. 2001. Legislative Response to Direct Legislation. In Referendum Democracy: Citizens, Elites, and Deliberation in Referendum Campaigns, Matthew Mendelsohn and Andres Parkin, eds., 191 - 210. New York: Palgrave.

Gilligan, Thomas W. and Krehbiel, Keith. 1987. Collectiove Decision-making and Standing Committees: An Informational Rationale for Restrictive Amendment Procedures. Journal of Law, Economics, and Organizations 3 (Fall): 287 - 335.

Howell, William, Adler, Scott, Cameron, Charles, and Rieman, Charles. 2000. Divided Government and the Legislative Productivity of Congress, 1945 - 1994. Legislative Studies Quarterly 25: 285 - 312.

Initiative and Referendum Institute at the University of Southern California. [Online], [cited 1 March 2009]. Available from <http://www.iandrinstitute.org/>.

Kelly, Sean Q. 1993. Divided We Govern? A Reassessment. Polity 25: 475 - 84.

King, James D. 2000. Changes in Professionalism in U.S. State Legislatures. Legislative Studies Quarterly 25: 327 - 43.

Krehbiel, Keith. 1998. Pivotal Politics: A Theory of U.S. Lawmaking. Chicago: University of Chicago Press.

Leigh, Andrew. 2008. Estimating the Impact of Gubernatorial Partisanship on Policy Settings and Economic Outcomes: A Regression Discontinuity Approach. European Journal of Political Economy 24 (1): 256 - 68.

Magleby, David. 1984. Direct Legislation: Voting on Ballot Propositions in the United States. Baltimore: Johns Hopkins University Press.

Marschall, Melissa and Anirudh V.S. Ruhil. 2005. Fiscal Effects of the Voter Initiative Reconsidered: Addressing Endogeneity. State Politics and Policy Quarterly 5 (4): 327 55. 
Matsusaka, John G. 1995. Fiscal Effects of the Voter Initiative: Evidence from the Last 30 Years. Journal of Political Economy 103: 587 - 623.

Matsusaka, John G. 2000. Fiscal Effects of the Voter Initiative in the First Half of the Twentieth Century. Journal of Law and Economics 43 (2): 619 - 50.

Matsusaka, John G. 2004. For the Many or the Few: The Initiative, Public Policy, and American Democracy. Chicago. University of Chicago Press.

Matsusaka, John G. 2005. The Endogeneity of the Initiative: Comment on Marschall and Ruhill. State Politics and Policy Quarterly 5 (4): 356 - 63.

Matsusaka, John G. 2007. "Disentangling the Direct and Indirect Effects of the Voter Initiative Process." Working Paper. University of Southern California. Available from: <http://www-rcf.usc.edu/ matsusak/Papers/Matsusaka Direct vs Indirect 2007.pdf>.

Matsusaka, John G. Forthcoming. Direct Democracy and Public Employees. American Economic Review.

Matsusaka, John G. and Nolan M. McCarty. 2001. Political Resource Allocation: Benefits and Costs of Voter Initiatives. Journal of Law, Economics, and Organization 17: 413 - 38.

Mayhew, David R. 1974. Congress: The Electoral Connection. New Haven: Yale University Press.

Mayhew, David R. 1991. Divided We Govern: Party Control, Lawmaking, and Investigations, 1946 - 1990. New Haven: Yale University Press.

Nelson, Douglas and Eugene Silberberg. 1987. Ideology and Legislator Shirking. Economic Inquiry. 25 (1): $15-25$.

Rogers, James R. 2002. Free Riding in State Legislatures. Public Choice 113 (1-2): $59-76$.

Rogers, James R. 2005. The Impact of Divided Government on Legislative Production. Public Choice 123 (1-2): 217 - 33.

Squire, Peverill. 1992. Legislative Professionalism and Membership Diversity in State Legislatures. Legislative Studies Quarterly XVII: 69 - 79.

Statistical Abstract of the United States [Online], (cited 1 June 2007). Available from: $<$ http://www.census.gov/compendia/statab/past_years.html $>$. 
Tolbert, Caroline, John Grummel, and Daniel Smith. 2001. The Effects of Ballot Initiatives on Voter Turnout in the American States. American Politics Research 29 (6): 625 - 48.

Tollison, Robert D. 1988. Public Choice and Legislation. Virginia Law Review 74 (March): $339-71$. 


\section{Author Biography}

Gregory Randolph is an assistant professor of economics at Southern New Hampshire University. He received his doctorate in economics from West Virginia University. His current research projects include examining the impact of direct democracy on policy outcomes and analyzing the behavior of interest groups at the state level. 
Table 1: The Voter Initiative States

\begin{tabular}{lcccc}
\hline $\begin{array}{c}\text { State (Date Initiative } \\
\text { Process Adopted) }\end{array}$ & $\begin{array}{c}\text { Signature } \\
\text { Requirement }\end{array}$ & $\begin{array}{c}\text { Qualification } \\
\text { Difficulty } \\
\text { Index }^{\mathrm{b}}\end{array}$ & $\begin{array}{c}\text { Legislative } \\
\text { Insulation } \\
\text { Index }^{\mathrm{b}}\end{array}$ & $\begin{array}{c}\text { Average Number } \\
\text { of Voter }^{\text {Initiatives }}{ }^{\mathrm{c}}\end{array}$ \\
\hline Alaska (1959) & 10 & 4 & 2 & 2.00 \\
Arizona (1912) & 10 & 7 & 4 & 2.93 \\
Arkansas (1909) & 8 & 8 & 5 & 1.56 \\
California (1911) & 5 & 9 & 9 & 9.00 \\
Colorado (1912) & 5 & 7 & 6 & 5.13 \\
Florida (1972) & 8 & 5 & 3 & 1.31 \\
Idaho (1912) & 6 & 6 & 5 & 1.06 \\
Illinois (1902) & 8 & 5 & 3 & 0.06 \\
Maine (1908) & 10 & 2 & 3 & 2.00 \\
Massachusetts (1918) & 3.5 & 2 & 4 & 2.56 \\
Michigan (1908) & 8 & 7 & 5 & 1.94 \\
Mississippi (1992) & 12 & 3 & 2 & 0.50 \\
Missouri (1906) & 5 & 4 & 4 & 1.94 \\
Montana (1904) & 5 & 4 & 4 & 2.75 \\
Nebraska (1912) & 7 & 4 & 3 & 1.06 \\
Nevada (1904) & 10 & 5 & 3 & 1.62 \\
North Dakota (1914) & 2 & 7 & 6 & 2.44 \\
Ohio (1912) & 6 & 4 & 5 & 1.81 \\
Oklahoma (1907) & 8 & 6 & 4 & 1.13 \\
Oregon (1902) & 6 & 7 & 7 & 8.19 \\
South Dakota (1898) & 5 & 6 & 5 & 2.13 \\
Utah (1900) & 10 & 6 & 4 & 0.94 \\
Washington (1912) & 8 & 6 & 4 & 4.63 \\
Wyoming (1968) & 15 & 1 & 1 & 0.38 \\
\hline a. & 5 & 5 & \\
\hline
\end{tabular}

a. The signature requirement for statutes was included for all states with the exception of Florida and Mississippi. The signature requirement for constitutional amendments was used for Florida and Mississippi because they only allow constitutional amendments.

b. The indices are developed in Bowler and Donovan (2004). The qualification difficulty index ranges from 1 to 6 with the difficulty in qualifying a voter initiative for the ballot decreasing as the values increase. The legislative insulation index ranges from 1 to 9 with the insulation to the legislature decreasing as the values increase. States that lack the voter initiative process receive a value of 0 .

c. The average number of voter initiatives is calculated as the average number of voter initiatives that appear on the ballot each two year election cycle from 1970 - 2002. Mississippi gained access to the voter initiative process in 1992 . The average for Mississippi refers to years $1994-2002$. 
Table 2: Data Sources and Variable Definitions

\begin{tabular}{|c|c|c|}
\hline Variable & Definition & Source \\
\hline Number of Bills Enacted & Number of bills enacted in state regular legislative session & a \\
\hline Number of Special Sessions & Number of special sessions called in states & a \\
\hline $\begin{array}{l}\text { Number of Gubernatorial } \\
\text { Vetoes }\end{array}$ & $\begin{array}{l}\text { Number of gubernatorial vetoes state regular legislative } \\
\text { session }\end{array}$ & $\mathrm{a}$ \\
\hline Initiative & $=1$ for states in which the voter initiative is available & $\mathrm{b}$ \\
\hline Signature Requirement & $=$ percentage signature requirement for initiative states & $\mathrm{b}$ \\
\hline Population $(\log )$ & Log of the population (in 1000's) & $\mathrm{c}$ \\
\hline Session Length & Number of legislative work days in the regular session & $\mathrm{a}$ \\
\hline Bill Single Subject Clause & $=1$ for states that restrict bills to a single subject & d \\
\hline $\begin{array}{l}\text { Revenue Bill Origination } \\
\text { Clause }\end{array}$ & $\begin{array}{l}=1 \text { for states in which revenue bills must originate in the } \\
\text { house chamber }\end{array}$ & $\mathrm{d}$ \\
\hline Divided Legislature & $\begin{array}{l}=1 \text { for states in which legislative chambers have opposing } \\
\text { majority parties }\end{array}$ & a \\
\hline Opposite Party Governor & $\begin{array}{l}=1 \text { for states in which a unified legislature face an opposite } \\
\text { party governor }\end{array}$ & $\mathrm{a}$ \\
\hline Republican Governor & $=1$ for states with a republican governor & a \\
\hline House Republicans (\% log) & Log of the percentage of republicans in lower chamber & a \\
\hline Senate Republicans $(\% \log )$ & Log of the percentage of republicans in upper chamber & a \\
\hline House Turnover $(\%)$ & $\begin{array}{l}\text { Percentage newly elected legislator from previous years lower } \\
\text { chamber election }\end{array}$ & a \\
\hline Senate Turnover $(\%)$ & $\begin{array}{l}\text { Percentage newly elected legislator from previous years upper } \\
\text { chamber election }\end{array}$ & a \\
\hline House Standing Committees & Number of standing committees in the lower chamber & a \\
\hline Senate Standing Committees & Number of standing committees in the upper chamber & a \\
\hline Joint Standing Committees & Number of joint standing committees & a \\
\hline Number of House Legislators & Number of legislators in the lower chamber & a \\
\hline Number of Senate Legislators & Number of legislators in the upper chamber & a \\
\hline House Staff & Average staff allocated to lower chamber legislators & a \\
\hline Senate Staff & Average staff allocated to upper chamber legislators & a \\
\hline Legislative Professionalism & Index by Squire (1992) and King (2000) on a scale of 0 to 1 & $\mathrm{f}$ \\
\hline Legislative Scope Limits & $\begin{array}{l}=1 \text { for states that limit the scope of legislative regular } \\
\text { sessions }\end{array}$ & d \\
\hline State Government Ideology & $=0-100$; higher scores indicating a more liberal government. & $\mathrm{g}$ \\
\hline Qualification Difficulty Index & $\begin{array}{l}\text { Measures difficulty of qualifying a proposition for the ballot; } \\
\text { ranges from } 0-6 \text {; easier to qualify for higher values. }\end{array}$ & $\mathrm{e}$ \\
\hline Legislative Insulation Index & $\begin{array}{l}\text { Measures the ability of the legislature to alter successful voter } \\
\text { initiatives; ranges from } 0-9 \text {; less ability for the state } \\
\text { legislature to alter outcomes for higher values. }\end{array}$ & $\mathrm{e}$ \\
\hline Average \# of Voter Initiatives & $\begin{array}{l}\text { Average number of voter initiatives appearing on the ballot } \\
\text { over each two year election cycle from } 1970-2000\end{array}$ & $\mathrm{~b}$ \\
\hline
\end{tabular}

Sources:

a: The Book of the States

b: Initiative and Referendum Institute

c: Statistical Abstract of the U.S., U.S. Census Bureau

d: National Conference of State Legislators e: Bowler and Donovan (2004)

f: Squire (1992) and King (2000)

g: Berry et al. (1998) 
Table 3: Descriptive Statistics

\begin{tabular}{lcccc}
\hline \multicolumn{1}{c}{ Variable } & Average & $\begin{array}{c}\text { Standard } \\
\text { Deviation }\end{array}$ & $\begin{array}{c}\text { Maximum } \\
\text { Value }\end{array}$ & $\begin{array}{c}\text { Minimum } \\
\text { Value }\end{array}$ \\
\hline Number of Bills Enacted (per year) & 484.42 & 352.76 & 3,068 & 34 \\
State Population (in thousands) & 5,101 & 5,513 & 34,533 & 416 \\
Session Length & 79.71 & 58.18 & 731 & 372 \\
House Standing Committees & 19.23 & 10.08 & 59 & 0 \\
Senate Standing Committees & 14.83 & 6.56 & 38 & 0 \\
Joint Standing Committees & 2.77 & 5.85 & 24 & 0 \\
House Legislators & 111.30 & 55.20 & 40 & 400 \\
Senate Legislators & 39.79 & 10.55 & 20 & 67 \\
House Staff & 1.07 & 0.75 & 3 & 0 \\
Senate Staff & 1.17 & 0.68 & 3 & 0 \\
Legislative Professionalism & 0.27 & 0.15 & 0.90 & 0.04 \\
State Government Ideology & 49.45 & 24.17 & 97.92 & 0.00 \\
Average \# Voter Initiatives & 1.16 & 1.97 & 9 & 0 \\
\hline
\end{tabular}

Notes: The dependent variable is the number of bills enacted by the American states during the regular legislative session in odd years from 1981 - 1995, 1998, 2000, and 2001. While almost all states hold legislative sessions annually, the dependent variable and a number of the independent variables are reported biennially in The Book of the States (Rogers, 2005). 
Table 4: Number of Bills Enacted

\begin{tabular}{|c|c|c|c|c|c|c|}
\hline \multirow{2}{*}{$\begin{array}{l}\text { Independent } \\
\text { Variable }\end{array}$} & \multicolumn{6}{|c|}{ Coefficient Estimates (standard errors are in parenthesis) } \\
\hline & (a) & (b) & (c) & (d) & (e) & (f) \\
\hline Voter Initiative & $\begin{array}{l}67.77 * \\
(35.75)\end{array}$ & $\begin{array}{c}67.77 \\
(69.91)\end{array}$ & -- & --- & $\begin{array}{l}-401.49 * * * \\
(129.65)\end{array}$ & --- \\
\hline $\begin{array}{l}\text { Qualification } \\
\text { Difficulty Index }\end{array}$ & -- & -- & $\begin{array}{c}39.83 * * * \\
(14.64)\end{array}$ & --- & $\begin{array}{l}94.32 * \\
(57.18)\end{array}$ & --- \\
\hline $\begin{array}{l}\text { Legislative } \\
\text { Insulation Index }\end{array}$ & -- & -- & -- & $\begin{array}{l}32.00 * * * \\
(12.32)\end{array}$ & $\begin{array}{c}19.99 \\
(42.31)\end{array}$ & --- \\
\hline $\begin{array}{l}\text { Average \# of } \\
\text { Voter Initiatives }\end{array}$ & -- & --- & -- & --- & -- & $\begin{array}{c}83.03 * * * \\
(21.81)\end{array}$ \\
\hline Population (log) & $\begin{array}{c}137.56 * * * \\
(26.96)\end{array}$ & $\begin{array}{c}137.56^{* *} \\
(54.22)\end{array}$ & $\begin{array}{c}126.58 * * \\
(52.71)\end{array}$ & $\begin{array}{c}126.46 * * \\
(53.92)\end{array}$ & $\begin{array}{c}100.32 * * \\
(49.11)\end{array}$ & $\begin{array}{r}98.08 * * \\
(47.66)\end{array}$ \\
\hline Session Length & $\begin{array}{c}0.79 * * * \\
(0.30)\end{array}$ & $\begin{array}{l}0.79 * \\
(0.46)\end{array}$ & $\begin{array}{l}0.71 * \\
(0.42)\end{array}$ & $\begin{array}{l}0.81^{*} \\
(0.45)\end{array}$ & $\begin{array}{c}0.71 \\
(0.49)\end{array}$ & $\begin{array}{c}0.57 \\
(0.39)\end{array}$ \\
\hline $\begin{array}{l}\text { Bill Single } \\
\text { Subject Clause }\end{array}$ & $\begin{array}{l}-239.48^{* * * *} \\
(63.07)\end{array}$ & $\begin{array}{l}-239.49 * \\
(136.51)\end{array}$ & $\begin{array}{l}-192.76 \\
(118.52)\end{array}$ & $\begin{array}{l}-186.07 \\
(114.97)\end{array}$ & $\begin{array}{l}-201.46^{*} \\
(117.13)\end{array}$ & $\begin{array}{l}-150.89 \\
(113.59)\end{array}$ \\
\hline $\begin{array}{l}\text { Revenue Bill } \\
\text { Origination }\end{array}$ & $\begin{array}{l}-57.46 \\
(36.35)\end{array}$ & $\begin{array}{l}-57.46 \\
(74.39)\end{array}$ & $\begin{array}{l}-69.70 \\
(74.99)\end{array}$ & $\begin{array}{l}-52.04 * \\
(77.77)\end{array}$ & $\begin{array}{l}-91.11 \\
(79.14)\end{array}$ & $\begin{array}{l}-111.29 \\
(75.65)\end{array}$ \\
\hline $\begin{array}{l}\text { Divided } \\
\text { Legislature }\end{array}$ & $\begin{array}{l}-48.07 \\
(43.03)\end{array}$ & $\begin{array}{l}-48.07 \\
(59.89)\end{array}$ & $\begin{array}{l}-45.74 \\
(58.06)\end{array}$ & $\begin{array}{l}-49.35 \\
(56.96)\end{array}$ & $\begin{array}{l}-45.25 \\
(57.77)\end{array}$ & $\begin{array}{l}-35.39 \\
(52.01)\end{array}$ \\
\hline $\begin{array}{l}\text { Opposite Party } \\
\text { Governor }\end{array}$ & $\begin{array}{c}-6.57 \\
(35.25)\end{array}$ & $\begin{array}{c}-6.57 \\
(33.11)\end{array}$ & $\begin{array}{c}-2.59 \\
(31.58)\end{array}$ & $\begin{array}{c}-3.86 \\
(30.92)\end{array}$ & $\begin{array}{c}0.45 \\
(29.52)\end{array}$ & $\begin{array}{c}2.51 \\
(29.84)\end{array}$ \\
\hline $\begin{array}{l}\text { Republican } \\
\text { Governor }\end{array}$ & $\begin{array}{l}102.02 * * \\
(41.09)\end{array}$ & $\begin{array}{c}102.02 * * \\
(51.35)\end{array}$ & $\begin{array}{l}94.77 * \\
(48.84)\end{array}$ & $\begin{array}{c}102.75 * * \\
(49.24)\end{array}$ & $\begin{array}{c}65.91 \\
(46.13)\end{array}$ & $\begin{array}{c}54.45 \\
(43.84)\end{array}$ \\
\hline $\begin{array}{l}\text { House Republican } \\
(\% \log )\end{array}$ & $\begin{array}{c}28.70 \\
(57.24)\end{array}$ & $\begin{array}{c}28.70 \\
(89.05)\end{array}$ & $\begin{array}{l}-5.15 \\
(82.06)\end{array}$ & $\begin{array}{l}-4.96 \\
(76.62)\end{array}$ & $\begin{array}{l}-83.25 \\
(69.62)\end{array}$ & $\begin{array}{l}-59.18 \\
(70.25)\end{array}$ \\
\hline $\begin{array}{l}\text { Senate Republican } \\
(\% \log )\end{array}$ & $\begin{array}{l}-41.94 \\
(52.69)\end{array}$ & $\begin{array}{l}-41.94 \\
(62.87)\end{array}$ & $\begin{array}{l}-34.58 \\
(61.75)\end{array}$ & $\begin{array}{l}-35.84 \\
(60.49)\end{array}$ & $\begin{array}{c}16.72 \\
(60.49)\end{array}$ & $\begin{array}{l}-10.73 \\
(59.28)\end{array}$ \\
\hline $\begin{array}{l}\text { House Turnover } \\
(\%)\end{array}$ & $\begin{array}{l}-1.66 \\
(1.91)\end{array}$ & $\begin{array}{l}-1.66 \\
(1.74)\end{array}$ & $\begin{array}{l}-1.81 \\
(1.73)\end{array}$ & $\begin{array}{l}-2.07 \\
(1.70)\end{array}$ & $\begin{array}{l}-1.37 \\
(1.75)\end{array}$ & $\begin{array}{l}-2.14 \\
(1.73)\end{array}$ \\
\hline $\begin{array}{l}\text { Senate Turnover } \\
(\%)\end{array}$ & $\begin{array}{l}-1.37 \\
(1.73)\end{array}$ & $\begin{array}{l}-1.37 \\
(1.15)\end{array}$ & $\begin{array}{l}-0.99 \\
(1.08)\end{array}$ & $\begin{array}{l}-0.96 \\
(1.07)\end{array}$ & $\begin{array}{l}-1.42 \\
(0.97)\end{array}$ & $\begin{array}{l}-0.47 \\
(1.02)\end{array}$ \\
\hline $\begin{array}{l}\text { House Standing } \\
\text { Committees }\end{array}$ & $\begin{array}{c}-7.15 * * * \\
(2.73)\end{array}$ & $\begin{array}{l}-7.15 \\
(5.78)\end{array}$ & $\begin{array}{l}-6.19 \\
(6.00)\end{array}$ & $\begin{array}{l}-6.54 \\
(5.99)\end{array}$ & $\begin{array}{l}-4.23 \\
(5.31)\end{array}$ & $\begin{array}{l}-2.94 \\
(5.56)\end{array}$ \\
\hline $\begin{array}{l}\text { Senate Standing } \\
\text { Committees }\end{array}$ & $\begin{array}{l}-0.47 \\
(3.92)\end{array}$ & $\begin{array}{l}-0.47 \\
(8.29)\end{array}$ & $\begin{array}{c}0.15 \\
(8.45)\end{array}$ & $\begin{array}{c}0.83 \\
(8.58)\end{array}$ & $\begin{array}{c}0.52 \\
(8.41)\end{array}$ & $\begin{array}{l}-4.32 \\
(7.61)\end{array}$ \\
\hline
\end{tabular}


Table 4: Number of Bills Enacted (Continued)

\begin{tabular}{|c|c|c|c|c|c|c|}
\hline $\begin{array}{l}\text { Joint Standing } \\
\text { Committees }\end{array}$ & $\begin{array}{l}-4.74 \\
(3.80)\end{array}$ & $\begin{array}{l}-4.74 \\
(5.83)\end{array}$ & $\begin{array}{l}-4.33 \\
(5.99)\end{array}$ & $\begin{array}{l}-3.11 \\
(5.99)\end{array}$ & $\begin{array}{c}0.39 \\
(6.07)\end{array}$ & $\begin{array}{l}-5.83 \\
(5.58)\end{array}$ \\
\hline $\begin{array}{l}\text { Number of House } \\
\text { Legislators }\end{array}$ & $\begin{array}{c}0.47 \\
(0.37)\end{array}$ & $\begin{array}{c}0.47 \\
(0.53)\end{array}$ & $\begin{array}{c}0.52 \\
(0.51)\end{array}$ & $\begin{array}{c}0.50 \\
(0.50)\end{array}$ & $\begin{array}{c}0.45 \\
(0.43)\end{array}$ & $\begin{array}{c}0.29 \\
(0.43)\end{array}$ \\
\hline $\begin{array}{l}\text { Number of Senate } \\
\text { Legislators }\end{array}$ & $\begin{array}{l}3.11 * \\
(1.80)\end{array}$ & $\begin{array}{c}3.11 \\
(3.65)\end{array}$ & $\begin{array}{c}3.30 \\
(3.56)\end{array}$ & $\begin{array}{c}3.02 \\
(3.51)\end{array}$ & $\begin{array}{c}2.91 \\
(3.34)\end{array}$ & $\begin{array}{l}4.21 \\
(3.45)\end{array}$ \\
\hline House Staff & $\begin{array}{c}12.15 \\
(32.75)\end{array}$ & $\begin{array}{c}12.15 \\
(33.27)\end{array}$ & $\begin{array}{c}8.35 \\
(31.93)\end{array}$ & $\begin{array}{c}12.66 \\
(32.17)\end{array}$ & $\begin{array}{c}6.15 \\
(33.37)\end{array}$ & $\begin{array}{c}14.82 \\
(30.96)\end{array}$ \\
\hline Senate Staff & $\begin{array}{c}-33.64 \\
(34.08)\end{array}$ & $\begin{array}{c}-33.64 \\
(36.55)\end{array}$ & $\begin{array}{c}-20.34 \\
(34.20)\end{array}$ & $\begin{array}{l}-22.01 \\
(34.53)\end{array}$ & $\begin{array}{c}-34.88 \\
(34.97)\end{array}$ & $\begin{array}{c}-7.67 \\
(35.12)\end{array}$ \\
\hline $\begin{array}{l}\text { Legislative } \\
\text { Professionalism }\end{array}$ & $\begin{array}{c}-43.18 \\
(172.30)\end{array}$ & $\begin{array}{c}-43.18 \\
(516.41)\end{array}$ & $\begin{array}{l}-138.24 \\
(470.62)\end{array}$ & $\begin{array}{l}-216.80 \\
(458.84)\end{array}$ & $\begin{array}{c}-93.29 \\
(413.27)\end{array}$ & $\begin{array}{l}-383.59 \\
(343.93)\end{array}$ \\
\hline Ideology & $\begin{array}{l}2.20 * * \\
(0.96)\end{array}$ & $\begin{array}{c}2.20 \\
(1.37)\end{array}$ & $\begin{array}{l}2.29 * \\
(1.31)\end{array}$ & $\begin{array}{l}2.66^{*} \\
(1.40)\end{array}$ & $\begin{array}{c}1.57 \\
(1.32)\end{array}$ & $\begin{array}{c}0.98 \\
(1.14)\end{array}$ \\
\hline North & $\begin{array}{l}-23.47 \\
(76.02)\end{array}$ & $\begin{array}{c}-23.47 \\
(153.16)\end{array}$ & $\begin{array}{c}70.39 \\
(143.75)\end{array}$ & $\begin{array}{c}62.32 \\
(145.08)\end{array}$ & $\begin{array}{c}114.22 \\
(123.29)\end{array}$ & $\begin{array}{c}129.47 \\
(136.05)\end{array}$ \\
\hline South & $\begin{array}{c}201.88^{* * * *} \\
(53.35)\end{array}$ & $\begin{array}{c}201.88^{* * *} \\
(90.11)\end{array}$ & $\begin{array}{c}249.38 * * * \\
(96.21)\end{array}$ & $\begin{array}{c}227.23 * * \\
(98.02)\end{array}$ & $\begin{array}{c}307.79 * * * \\
(87.17)\end{array}$ & $\begin{array}{c}243.01 * * * \\
(89.93)\end{array}$ \\
\hline West & $\begin{array}{l}230.75^{* * * *} \\
(49.49)\end{array}$ & $\begin{array}{l}230.75^{* *} \\
(111.20)\end{array}$ & $\begin{array}{l}226.46 * * \\
(104.69)\end{array}$ & $\begin{array}{c}205.75 * * \\
(103.93)\end{array}$ & $\begin{array}{l}254.84 * * * \\
\quad(93.51)\end{array}$ & $\begin{array}{c}82.19 \\
(87.88)\end{array}$ \\
\hline Constant & $\begin{array}{l}-1623.76 \\
(370.81)\end{array}$ & $\begin{array}{l}-1623.76 \\
(759.31)\end{array}$ & $\begin{array}{l}-1497.92 \\
(735.69)\end{array}$ & $\begin{array}{c}-1501.50 \\
(752.15)\end{array}$ & $\begin{array}{l}-979.66 \\
(667.50)\end{array}$ & $\begin{array}{l}-835.93 \\
(657.44)\end{array}$ \\
\hline R-Squared & 0.33 & 0.33 & 0.37 & 0.37 & 0.41 & 0.41 \\
\hline
\end{tabular}

Note: The dependent variable is the number of bills enacted in the American states during the regular legislative session every other year from 1981 - 1995, 1998, 2000, \& 2001. While almost all states hold legislative sessions annually, the dependent variable and a number of the independent variables are reported biennially in The Book of the States (Rogers, 2005). Standard errors are noted in parenthesis. There are 461 observations. Asterisks indicate significance as follows: $* * *=1 \%, * *=5 \%, *=$ $10 \%$. Year dummy variables are not reported. Clustered standard errors are employed at the state level in (b) through (f). 